\title{
Sensemaking in the Senate: A Congressional Fellow's Perspective of Life on the Hill
}

\author{
Paulina S. Rippere, Assistant Professor of Political Science, Jacksonville University
}

W hen I began the year as an APSA Congressional Fellow, I had no practical political experience. Despite writing a doctoral dissertation on party polarization in Congress and reading numerous books and articles on everything from the "folkways" of the Senate (Matthews 1959) to the theory of Conditional Party Government (Rohde 1991), when I arrived on the Hill, I felt like a fish out of water. After completing several interviews in different House and Senate offices to secure a placement for the fellowship year, I started to gain my bearings. I began to feel more comfortable with how the interviews were typically conducted, to anticipate the questions I would be asked, and, most importantly, to navigate the underground subway system to find my way from one office building to the next. At about this time, it occurred to me: I was experiencing the process of "sensemaking," the very topic I had come to Washington to study.

The concept of "sensemaking" is introduced in the literature on organizational theory, and it is described as the process by which people "make sense" of the environment around them. Scholars define sensemaking as "a process in which individuals develop cognitive maps of their environment" (Ring and Rands 1989, 342). These "frame[s] of reference" (Weick 1995, 4) allow us "to comprehend, understand, explain, attribute, extrapolate, and predict" (Starbuck and Milliken 1988, 51), and we tend to rely on sensemaking most when we find ourselves in an unfamiliar situation. Most important, sensemaking should be understood as a process, rather than as an outcome. It is retrospective, social, ongoing, grounded in identity construction, focused on and by extracted cues, and driven by plausibility rather than accuracy (Weick 1995, 17).

Sensemaking can also be understood as a social activity. When newcomers join and are socialized into an organization, the process of sensemaking has "a strong influence on the manner by which individuals within organizations begin processes of transacting with others," (Ring and Van de Ven 1989, 180). As they adapt to their new surroundings, it is necessary "for organizational members to understand and to share understandings about such features of the organization as what it is about, what it does well and poorly, what the problems it faces are, and how it should resolve them" (Feldman $1989,19)$. This process of sharing information helps newcomers understand the goals and strengths of the group.

What I wanted most out of the APSA fellowship was to discover how legislators learn to do their jobs and what cognitive shortcuts they use to make sense of the new environment in which they are

Paulina S. Rippere is assistant professor of political science at Jacksonville University in Jacksonville, Florida. Her research interests include the US Congress, political parties and polarization, American political development, and campaigns and elections. She was awarded an American Political Science Association Congressional Fellowship for 2014-2015 and spent the year working in Congress as a legislative assistant to senator Jack Reed (RI). She can be contacted at pripper@ju.edu. placed upon their election to office. I was also curious about what influence-if any-the structure of the institution and social relationships among colleagues have on this learning process. Apart from brief orientation sessions held for newly-elected policymakers, there is almost no training for members beginning their legislative careers. The elaborate rules, procedures, and norms of each chamber and the lightning speed of daily life on the Hill means that new members face a steep learning curve with little room for error. Their multiple roles-lawmaker, public servant, policy expert, media commentator-only serve to complicate this learning process (Dodd 2002). To achieve their individual goals of winning reelection, writing policy, and obtaining power within the institution (Fenno 1978), they must take advantage of readily available cognitive shortcuts that help them make sense of their new working environment. Through the Congressional Fellowship Program, I observed several ways that legislators accomplish this.

\section{HOW MEMBERS-ELECT LEARN TO BE LEGISLATORS}

Before the start of each Congress, members-elect attend orientation sessions to learn the ins and outs of their new role as legislators. House freshmen attend panels and meetings over the course of two weeks, while senators-elect spend three days learning the ropes from more senior senators. New members receive instruction on a variety of topics, including the process of hiring staff and setting up an office, managing their budget, applying for committee assignments, and navigating congressional ethics rules. These sessions provide opportunities for House freshmen to get to know fellow newcomers and for newly-elected senators to meet some of their senior Senate colleagues.

Perhaps the most valuable source of information for new members is their staff. Before beginning my fellowship on the Hill, I did not fully appreciate the tremendous amount of work completed by a member's personal and committee staff. The policy and procedural expertise possessed by congressional staffers is astounding. When new members begin to set up their offices, they often seek out experienced staffers who bring with them the knowledge necessary for legislators to accomplish their goals. Talented veteran staffers can walk members through each stage of the legislative process and help them gain enough experience to make sense of the process on their own.

Finally, what really intrigues me-and has yet to be explored fully in the political science literature-is how legislators learn from each other. We know that legislators' relationships with their colleagues are important (Baker 1999; Dodd 2002; Caldeira and Patterson 1987 1988; Clark, Caldeira, and Patterson 1993; Arnold, Deen, and Patterson 2000; Peoples 2008), and this is particularly true in the Senate. The unique institutional rules and procedures of the Senate create an environment that is unpredictable, especially when compared to the hierarchical structure of the House of Representatives. 
When there is no unanimous consent agreement in place, the rules allow any individual senator to obstruct or to put a stop to the legislative process altogether. Even on "normal" legislative days (although I don't know that there is such a thing), the schedule can shift immediately, leaving senators and staffers rushing frantically from a committee hearing to the floor for an unexpected vote for which the member may or may not be adequately prepared. This experience is the reality of senators' daily lives, particularly those in the minority party.

The erratic work environment makes it difficult for senators to gain "a simple, generic, and structured understanding of Senate life" (Dodd 2002, 357). Senators must be able to adapt quickly to these shifting circumstances, and many find early on in their career that getting to know their colleagues is simply a smart decision. Basing these relationships on "a track record of trust derived from shared experiences, these peculiar friendships [or 'institutional kinships'] enable senators to save time in gathering information and cues and reduce transaction costs in their dealings with colleagues" (Baker 1999, 7). But how do senators form these relationships? This is another question I pondered throughout the course of my fellowship. Although there is no clear-cut answer, I made several observations that may be helpful in understanding legislative collaboration from an empirical perspective.

\section{SOURCES OF SENATE FRIENDSHIPS}

Senators form working relationships, and even friendships, with their colleagues in many ways, but two, in particular, stand out to me. First, some senators may create a connection through their or letters to colleagues or executive agencies. These connections may also provide opportunities for newly-elected senators to learn from their senior colleagues who can serve as mentors, guiding the junior members as they gain their bearings in their new profession. Of course, the extent of their collaboration can vary based on many factors, including the issue at hand, the size of their state, whether or not the senators are members of the same party, and whether or not the pair share similar personal communication styles.

Senators from the same geographic region often face similar incentives to cooperate. Working for Senator Jack Reed (D-RI), I focused much of my time on researching the New England energy and capacity markets. Finding ways to lower energy prices for Rhode Islanders and residents of the other New England states is a goal that connected not only Senators Reed and Sheldon Whitehouse (D-RI), but nearly all members of the New England delegation in the House and in the Senate. Such a complex policy problem requires a regional, rather than a local, solution and requires regular collaboration on the part of the members and their staff. The necessity of solving state or regional problems may also create the potential for the formation of bipartisan ties among senators. Repeatedly interacting with their Senate colleagues in face-to-face meetings on the Hill, at press events in their home states, and in meetings with federal administrators may help legislators establish the trust and respect necessary for collaboration to occur.

\section{BIPARTISANSHIP: DEAD OR ALIVE?}

A final observation gleaned from my time on the Hill differs from the standard portrayal of congressional party polarization and conflict

\section{What I wanted most out of the APSA fellowship was to discover how legislators learn to do their jobs and what cognitive shortcuts they use to make sense of the new environment in which they are placed upon their election to office.}

shared service as Chair and Ranking Member of a committee or subcommittee. In these roles, a Senate pair has a shared incentive to take up, process, and successfully report legislation that falls under their committee's jurisdiction. Should a bill they report make its way to the floor, the Chair and Ranking Member-now working together as bill managers-are even more highly motivated to manage conflict between their colleagues, make reasonable compromises, and pass the bill. By getting to know each other as leaders invested in their committee's success, such a bipartisan Senate pair can develop a collaborative relationship built on mutual trust and respect that may carry over into other policy areas they address in the future. Moreover, the nature of the relationship between Committee Chair and Ranking Member is a structural facet of the institution that requires a pair of senators from opposing political parties to work together to achieve a common goal. Conceivably, this aspect of the Senate's structure acts as a mechanism that promotes the development and maintenance of bipartisan relationships that help sustain the institution during highly polarizing and contentious times.

Second, serving from the same state or from the same geographic region can encourage the formation of a strong collaborative connection between senators. Same-state senators serve the same constituents and, as a result, are often asked to solve the same problems. This can create an incentive for them to cosponsor each other's legislation, attend the same events back home, and release joint statements in the media and in much of the academic literature. Despite high levels of party polarization observed over the last 10-20 years in legislators' roll call voting, I witnessed numerous examples of bipartisan collaboration in the Senate. Efforts to seek out bipartisan cosponsors who could serve as collaborators during the process of writing a bill or amendment and later in promoting the legislation occurred regularly; the knowledge that a bill needs bipartisan support to pass is woven into the fabric of Senate life. Although many Senate staffers, themselves, echoed the sentiment that gaining bipartisan support for legislation is very difficult in the current highly polarized environment, they actively sought senators from the other party to sign on as bipartisan cosponsors for most legislation introduced. Obtaining bipartisan support in the form of cosponsorship was considered essential in order to give the legislation a hope of receiving a vote, let alone passing the chamber. Granted, the feasibility of convincing a partisan opponent to sign on to legislation varies by senator and by issue; however, staffers know which senators are frequent cosponsors of their boss's proposals, which senators are long-shots but worth approaching, and which senators will be impossible to persuade. What is almost guaranteed-even in the highly polarized environment of today's Senate-is that if you want to get a vote, you have to have bipartisan support.

Overall, my experience as a Congressional Fellow was priceless. Working on the Hill helped me realize something that is lost on 
many political observers and voters: members of the US House and Senate are people, too. Some are extroverts who interact socially with a wide variety of their colleagues; others prefer to keep to themselves. Some are shrewd policy and procedural strategists who work their way up the institutional power ladder; many are content to represent their constituents as members of the rank-and-file. Some are showhorses who play to the cameras; others prefer to work quietly behind the scenes to enact incremental policy change. Despite these differences, it takes time for all new legislators to make sense of their surroundings, foster relationships with their colleagues, and become skilled members of the institution. Having the opportunity to see Congress from the inside has helped me to better understand what life on the Hill is really like and how future research can begin to examine concepts, like the social relationships between colleagues, that are difficult to measure but important influences on the legislative process.

\section{NOTES}

1. Bridget Bowman, "New Member Orientation Welcomes New Class of Lawmakers," 10 November 2014.

\section{RE F E R E N C E S}

Arnold, Laura W., Rebecca E. Deen, and Samuel C. Patterson. 20oo. "Friendship and Votes: The Impact of Interpersonal Ties on Legislative Decision Making." State and Local Government Review 32 (Spring): 142-7.

Baker, Ross K. 1999. Friend and Foe in the U.S. Senate. La Jolla, CA: Copley.

Caldeira, Gregory A., and Samuel C. Patterson. 1987. "Political Friendships in the Legislature." Journal of Politics 49 (November): 953-75.
. 1988. "Contours of Friendship and Respect in the Legislature." American Politics Research 16 (October): 466-85.

Clark, John A., Gregory A. Caldeira, and Samuel C. Patterson. 1993 "Political Respect in the Legislature." Legislative Studies Quarterly 18 (February): 3-28.

Dodd, Lawrence C. 2002. "Making Sense out of Our Exceptional Senate: Perspectives and Commentary." In U.S. Senate Exceptionalism, ed. Bruce I. Oppenheimer. Columbus, OH: Ohio State University Press.

Feldman, Martha S. 1989. Order Without Design: Information Production and Policy Making. Stanford, CA: Stanford University Press.

Fenno, Richard. 1978. Home Style: House Members in their Districts. Boston: Little, Brown and Co.

Matthews, Donald R. 1959. “The Folkways of the United States Senate: Conformity to Group Norms and Legislative Effectiveness." American Political Science Review 53 (December): 1064-89.

Peoples, Clayton D. 2008. "Interlegislator Relations and Policy Making: A Sociological Study of Roll-Call Voting in a State Legislature." Sociological Forum 23 (September): 455-80.

Ring, Peter S., and Gordon P. Rands. 1989. "Sensemaking, Understanding, and Committing: Emergent Interpersonal Transaction Processes in the Evolution of 3M's Microgravity Research Program." In Research on the Management of Innovation: The Minnesota Studies, eds. Andrew H. Van de Ven, Harold.L. Angle, and Marshall S. Poole. New York: Ballinger.

Ring, Peter S., and Andrew H. Van de Ven. 1989. "Formal and Informal Dimensions of Transactions." In Research on the Management of Innovation: The Minnesota Studies, eds. Andrew H. Van de Ven, Harold.L. Angle, and Marshall S. Poole. New York: Ballinger.

Rohde, David W. 1991. Parties and Leaders in the Postreform House. Chicago: University of Chicago Press.

Starbuck, William H., and Frances J. Milliken. 1988. "Executives Perceptual Filters: What They Notice and How They Make Sense." In The Executive Effect:Concepts and Methods for Studying Top Managers, ed. Donald Hambrick. Greenwich, CT: JAI Press.

Weick, Karl E. 1995. Sensemaking in Organizations. Thousand Oaks, CA: Sage.

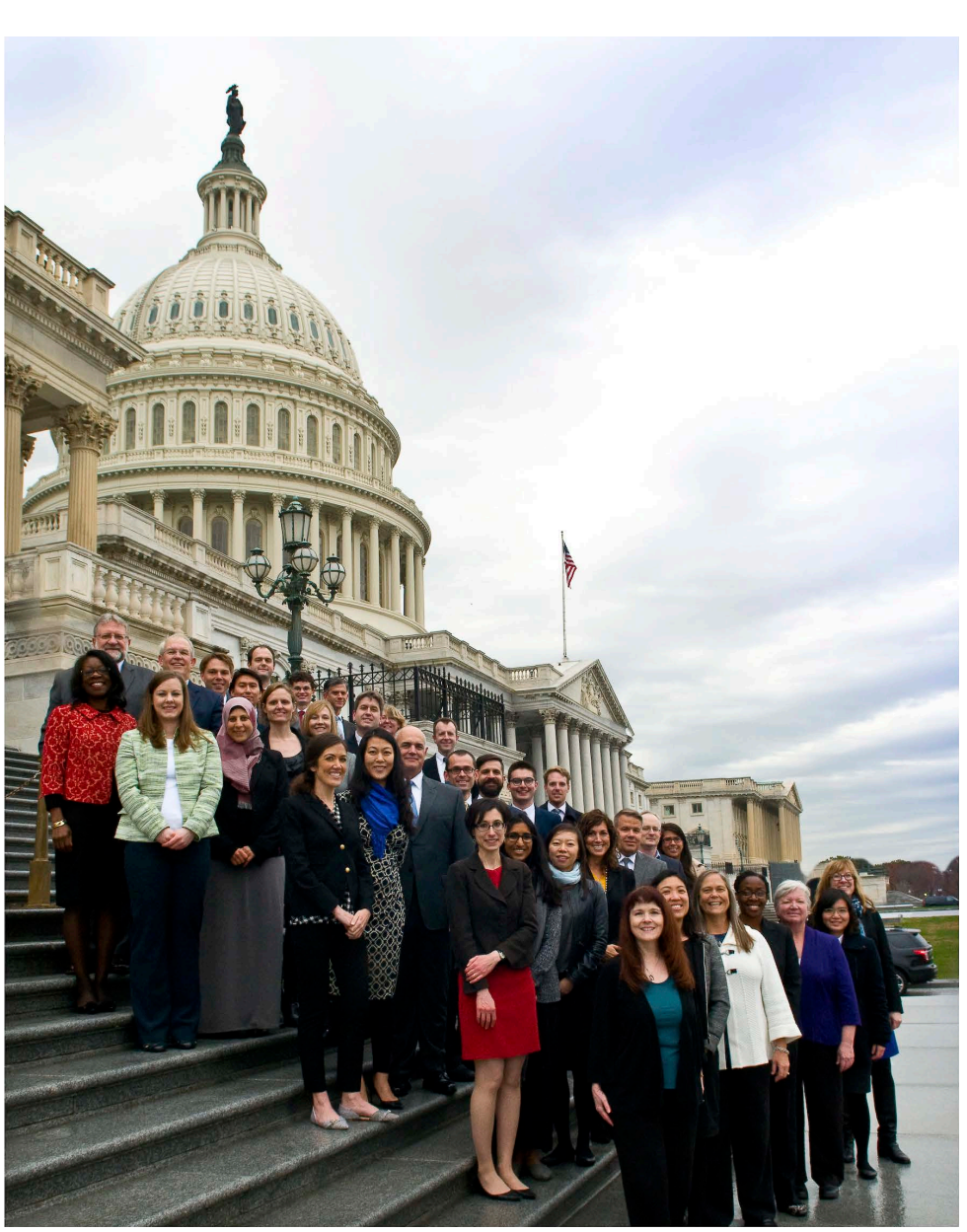

Top row, L to R: Dayna Matthew, David Keahey, Thomas Mayes, Mark Owens, Yushi Alex Saito, Nicholas Howard, Robert Ferguson, Randy Cartwright

Fourth row, L to R: Lisa Hager, Sarah Khasawinah, Jamie Kuhne, Julie Bobitt, Christopher Burdick, Shannon Dorsey, Brian Alexander

Third row, L to R: Megan Christensen, Jacquelyn Kung, Robert Mabry, Clayton Swope, Nathan Paxton, Elliot Mamet, Stephen Dietz

Second row, L to R: Kara Abramson, Hiral Shah, Y. Claire Wang, Stephanie Firestone, Ryan Matheny, Brian McCuen, Maria M. Givens

Bottom row, L to R: Teri Kennedy, Hillary Lum, Jamie Davis, Latrice Vinson, Jeanette Roberts, Nattamon Punbhochar, Rebecca Mabe

Not pictured: Gene Gerzhoy, Travis Johnston, Thomas Ringenberg, Joel Walsh, Justin Brown, Tamara Harris, Gina McCaskill, Julie Carter, Aditi Sen, La Rissa Ferrell 